\title{
The Relationship of Lumbar Multifidus Muscle Change to Disc Hernia and Low Back Pain: An Magnetic Resonance Imaging Study
}

\author{
Lomber Multifidus Kas Değișimiyle Disk Hernisi ve Bel Ağrısı Arasındaki ilișki: Bir \\ Manyetik Rezonans Görüntüleme Çalıșması
}

\section{(D) Emrah Sayıt}

University of Health Sciences, Samsun Traning and Research Hospital, Clinic of Orthopaedics and Traumatology, Samsun, Turkey

\begin{abstract}
Introduction: Our aim was to evaluate the relationship between lumbar multifidus (LM) muscle atrophy and lumbar disc herniation by magnetic resonance imaging (MRI) findings in patients with low back pain.

Methods: Lumbar MRI of 264 patients aged between 18 and 80 years who had a history of back pain for at least 6 months were evaluated retrospectively for LM muscle atrophy. LM muscle atrophy was evaluated at L4-5 and L5-S1 levels in axial T2-weighted images. The lumbar MRI of the patients were evaluated for LM muscle atrophy and lumbar intervertebral disc herniation. The relationship of LM muscle atrophy to lumbar intervertebral disc herniation and back pain was investigated statistically.

Results: Of 264 (147 female, 117 male) patients, 88 patients (33.3\%) had grade 0 atrophy, 135 (51.1\%) had grade 1 atrophy and $41(15.5 \%)$ had grade 2 atrophy. The prevalence of LM muscle atrophy was $73.5 \%$ in females and $49.8 \%$ in males. In 210 of 264 patients, intervertebral disc herniation was detected at any level in the lumbar spine. Of these 210 patients, 150 (71\%) had grade 1 and 2 LM muscle atrophy. Spinal canal stenosis, intervertebral disc herniation and nerve root compression were not detected in 54 of 264 patients. Of these 54 patients, 28 had grade 0 atrophy, 23 had grade 1 atrophy and 3 had grade 2 atrophy.

Conclusion: In our study, 9.8\% of patients with low back pain had grade 1 and 2 LM muscle atrophy without accompanying spinal canal stenosis, intervertebral disc herniation or nerve root compression. LM muscle atrophy alone may be the cause of low back pain in patients with normal MRI.
\end{abstract}

Keywords: Low back pain, lumbar disc herniation, magnetic resonance imaging, multifidus muscle
ÖZ

Amaç: Bizim buradaki amacımız kronik bel ağrısı ile lomber multifidus (LM) kas atrofisi arasındaki ilişkiyi manyetik rezonans görüntüleme (MRG) bulguları ile birlikte değerlendirmektir.

Yöntemler: En az 6 aydır sırt ağrısı şikayeti bulunan yaşları 18 ile 80 arasında değişen 264 hastanın lomber MRG'si retrospektif olarak LM kas atrofisi açısından değerlendirildi. LM kas atrofisi aksiyal T2 görüntülemelerde L4-5 ve L5-S1 düzeylerinden değerlendirildi. Hastaların lomber MRG'si LM kas atrofisi ve lomber intervertebral disk herniasyonu açısından değerlendirildi. LM atrofisinin lomber intervertebral disk herniasyounu ve bel ağrısı ile olan ilișkisi istatistiksel olarak araștırıldı.

Bulgular: İki yüz altmış dört (147 kadın, 117 erkek) hastanın lomber MRG'sinde 88 hastada $(\% 33,3)$ evre 0 atrofi, 135 hastada $(\% 51,1)$ evre 1 atrofi ve 41 hastada $(\% 15,5)$ evre 2 atrofi saptandı. Kadınlarda LM atrofisinin sıklığı \%73,5 olup erkeklerde \%49,8'dir. İki yüz altmıs dört hastanın 210'unda lomber vertebralarda herhangi bir seviyede intervertebral disk hernisi saptandı. İki yüz on hastanın 150'sinde (\%71) LM kasında evre 1 ve 2 atrofi saptandı. Iki yüz altmıs dört hastanın 54'ünde herhangi bir seviyede intervertebral disk herniasyonu, spinal kanal darlığı ve sinir kökü basısı saptanmadı. Bu 54 hastanın 28'inde evre 0 , 23'ünde evre 1 ve 3'ünde evre 2 atrofi saptandı.

Sonuç: Bizim yapmış olduğumuz çalıșmada lomber intervertebral disk herniasyonu, spinal kanal stenozu ve sinir kökü basısı mevcut olmayan tek şikayeti bel ağrısı olan \%9,8 olguda LM kasında evre 1 ve 2 atrofi saptanmıștır. Tamamen normal MRG'si olan olgularda LM kas atrofisi tek başına bel ağrısının nedeni olabilir.

Anahtar Kelimeler: Bel ağrısı, lomber disk hernisi, manyetik rezonans görüntüleme, multifidus kası
Address for Correspondence/Yazıșma Adresi: Emrah Sayıt, University of Health Sciences, Samsun Traning and Research Hospital, Clinic of Orthopaedics and Traumatology, Samsun, Turkey

Phone: +90 5056708662 E-mail: dremrahsayit@gmail.com ORCID ID: orcid.org/0000-0003-0733-8621

Cite this article as/Atıf: Sayıt E. The Relationship of Lumbar Multifidus Muscle Change to Disc Hernia and Low Back Pain: An Magnetic Resonance Imaging Study. İstanbul Med J 2019; 20(2): 111-4.
Received/Geliș Tarihi: 21.11.2017 Accepted/Kabul Tarihi: 16.07.2018

(c) Copyright 2019 by the Istanbul Training and Research Hospital/istanbul Medical Journal published by Galenos Publishing House.

(C) Telif Hakkı 2019 İstanbul Ĕgitim ve Araștırma Hastanesi/Istanbul Tıp Dergisi, Galenos Yayınevi tarafından basılmıștır. 


\section{Introduction}

Low back pain (LBP) is a common and often recurrent health problem. Approximately $80 \%$ of people have at least one case of LBP during their lifetime. Paraspinal muscles play a significant role in the stability and functional movements of the lumbar spine (1). The lumbar multifidus (LM) muscle is the main stabilizer of the lumbar spine, and is important for spinal motion and stability $(2,3)$. Dysfunction of the LM muscle has been found to be important in chronic and recurrent LBP (4). Chronic diseases and long-term neurological inhibition after trauma may cause muscle atrophy and may lead to the replacement of healthy LM muscle fibrils with adipose tissue (5). Morphological changes of LM muscles in patients with lumbosacral disc herniation have been reported in literature (6-9). Kim et al. (7) demonstrated that the cross-sectional areas of the LM muscle were reduced when the symptom duration was 6 months or longer in case of lumbar disc herniation. In addition, studies in the literature have shown that LBP and paraspinal muscle atrophy have a relationship (3-5). In this study, we evaluated the relationship between lumbar disc herniation and LM muscle atrophy in patients with LBP by using magnetic resonance imaging (MRI).

\section{Methods}

The University of Health Sciences, Samsun Training and Research Hospital Ethics Committee approval was received for this study (decision no: 2017/24). In total, 264 patients (range: 18-80 years) who suffered from LBP for six months or longer were retrospectively evaluated. Patients with spinal fractures, malignancy, intraspinal mass, spondylitis, previous surgery or structural deformity were not included the study.

\section{Radiological Protocol and Imaging}

The MRI images were obtained with a 1.5 Tesla MAGNETOM Aera ${ }^{\circledR}$ MRI device (Siemens Healthcare, Erlangen, Germany) with a body surface coil. The sequences included sagittal T1-weighted fast spin-echo (FSE) (TR/TE: 475/9.3), T2-weighted FSE (TR/TE: 3790/97) and axial T2-weighted FSE (TR/TE: 4271/108), $280 \mathrm{~mm}$ field of view, 180×256 matrix, and $4 \mathrm{~mm}$ section thickness, NEX 2 .

LM muscle atrophy was assessed at L4-L5 and L5-S1 levels in all patients. LM muscle was evaluated in three grades according to fatty atrophic changes, as grade 0 (fatty atrophy less than 10\%), grade 1 (fatty atrophy between $10 \%$ and $50 \%$ ) and grade 2 (fatty atrophy greater than 50\%) (Figure 1) (10,11). Evaluation of the fatty atrophic changes in the LM muscle was performed visually and it was conducted by a single researcher. The fatty infiltration percentages were bilaterally identical in all study groups.

\section{Statistical Analysis}

Statistical analysis was performed with SPSS software version 21 (IBM Corporation, Armonk, USA). Kolmogorov-Smirnov test was used to test the normal distribution of data. The results were presented as mean, standard deviation, minimum, maximum, frequency and percentage according to characteristics.
Independent Samples t test or univariate analysis of variance were used for intergroup comparisons. Chi-square test was used for the comparison of nominal variables. $\mathrm{P}<0.05$ was considered significant.

\section{Results}

\section{Patients}

One hundred and forty-seven women (62.3\%) and 117 men (37.7\%) with LBP were included in the study. The mean age was $47.6 \pm 14.0$ years (range $=18-80$ years). The mean age of the patients with and without lumbar intervertebral disc herniation at any level is shown Table 1.

\section{Imaging Results}

Two hundred and ten (115 female, 95 male) (79.5\%) patients were diagnosed as having lumbar intervertebral disc herniation at any level by MRI. Intervertebral disc herniation was not detected in 54 (32 female, 22 male) of 264 patients. The mean age of the patients with and without lumbar intervertebral disc herniation is shown in Table 1. Of 264 patients, 88 (33.3\%) had grade 0 atrophy, 135 (51.1\%) had grade 1 atrophy and 41 (15.5\%) had grade 2 atrophy. LM muscle atrophy was $73.5 \%$ in women and $49.8 \%$ in men $(p=0.01)$. In addition, LM muscle atrophy was more common in both male and female patients older than 40 years of age (Table 2). All LM muscles were bilaterally atrophic.

\begin{tabular}{|c|c|c|c|c|}
\hline $\begin{array}{l}\text { Intervertebral disc } \\
\text { herniation at any level }\end{array}$ & Grade & Female & Male & p \\
\hline \multirow{3}{*}{ With herniation $(n=210)$} & $0(n=60)$ & $\begin{array}{l}39.7 \pm 9.2 \\
(n=26)\end{array}$ & $\begin{array}{l}37.8 \pm 12.1 \\
(n=34)\end{array}$ & 0.12 \\
\hline & $1(n=112)$ & $\begin{array}{l}50.1 \pm 9.3 \\
(\mathrm{n}=62)\end{array}$ & $\begin{array}{l}49.8 \pm 10.6 \\
(n=50)\end{array}$ & 0.70 \\
\hline & $2(n=38)$ & $\begin{array}{l}64.7 \pm 6.6 \\
(n=27)\end{array}$ & $\begin{array}{l}64 \pm 15.7 \\
(n=11)\end{array}$ & 0.83 \\
\hline \multirow{3}{*}{$\begin{array}{l}\text { Without herniation } \\
(\mathrm{n}=54)\end{array}$} & $0(n=28)$ & $\begin{array}{l}34.1 \pm 10.1 \\
(n=13)\end{array}$ & $\begin{array}{l}32.8 \pm 11.1 \\
(n=15)\end{array}$ & 0.75 \\
\hline & $1(n=23)$ & $\begin{array}{l}43.6 \pm 13.3 \\
(n=16)\end{array}$ & $\begin{array}{l}53.7 \pm 14.5 \\
(n=7)\end{array}$ & 0.19 \\
\hline & $2(n=3)$ & $(n=3)$ & $(n=0)$ & * \\
\hline \multicolumn{5}{|c|}{$\begin{array}{l}\text { Grade } 0 \text { atrophy: fatty infiltration }<10 \% \text {, Grade } 1 \text { atrophy: fatty infiltration } 10 \%-50 \% \text {, } \\
\text { Grade } 2 \text { atrophy: fatty infiltration }>50 \%\end{array}$} \\
\hline \multicolumn{5}{|c|}{ *Comparison cannot be made because there were no male patients in this group } \\
\hline
\end{tabular}

\begin{tabular}{|c|c|c|c|c|}
\hline \multicolumn{5}{|c|}{ LM muscle atrophy } \\
\hline & $<40$ years & & $>40$ years & $\mathrm{p}$ \\
\hline \multirow{2}{*}{ Male } & Grade 0 & $31(75.6 \%)$ & Grade $0 \quad 18(23.6 \%)$ & \multirow{2}{*}{$<0.001$} \\
\hline & Grade $1+2$ & $10(24.4 \%)$ & Grade 1+2 58 (76.4\%) & \\
\hline \multirow{2}{*}{ Female } & Grade 0 & $25(60.9 \%)$ & Grade $0 \quad 14$ (13.2\%) & \multirow{2}{*}{$<0.001$} \\
\hline & Grade $1+2$ & $16(39.1 \%)$ & Grade $1+292$ (86.8\%) & \\
\hline
\end{tabular}

$50 \%$, Grade 2: fatty infiltration $>50 \%$ 
Disc herniation and LM muscle atrophy at L4-L5 level was significantly associated with age $(p=0.001$ and $p<0.001$, respectively), and disc herniation at L5-S1 level was not significantly associated with age $(p=0.49)$. The coexistence of LM muscle atrophy and disc hernia at both levels (LM muscle atrophy and disc herniation at L4-L5 level, $p=0.58$, LM muscle atrophy and disc herniation at L5-S1 level, $\mathrm{p}=0.87$ ) and disc herniation at L4-L5 and L5-S1 levels ( $p=0.36)$ were not associated with age.

The mean age of patients according to the grade of LM muscle atrophy is given in Table 3. There was a significant difference in the mean age of the patients with respect to different grades of LM muscle atrophy $(p<0.01)$. LM muscle atrophy was found to increase with age.

Of 54 patients without lumbar intervertebral disc herniation, 28 had grade 0 atrophy, 23 had grade 1 atrophy (Figures 2a, b), and 3 had grade 2 atrophy. In addition, there was no spinal stenosis or nerve root compression in MRI of 25 patients with grade 1 or $2 \mathrm{LM}$ muscle atrophy to explain the LBP. Moreover, 9.8\% of our patients with LBP had normal MRI except for those with LM muscle atrophy.

\section{Discussion}

The LM muscle is an important local stabilizer of the lumbar spine. It can be divided into superficial and deep fibers, each with different functions. Because the superficial and deep parts of the muscle are near the center of lumbar joint rotation, the deep fibers can control intervertebral movement and the superficial fibers are well-suited to control spine orientation (4). Increased fat infiltration of the LM muscle may lead to lumbar dysfunction and this may cause LBP $(9,12)$. Eating

\section{Table 3. The mean age of patients according to the grade of LM muscle atrophy, excluding the patients with disc herniation}

\begin{tabular}{|l|l|l|l|}
\hline LM muscle atrophy & Number of patients & Age (years) & p \\
\hline Grade 0 & 28 & $19.6 \pm 10.5$ & $<0.001$ \\
\hline Grade 1 & 23 & $33.9 \pm 14.1$ & $52.6 \pm 3.6$ \\
\hline Grade 2 & 3 & 28.6 & \\
\hline
\end{tabular}

LM: lomber multifidus, Grade 0: fatty atrophy $<10 \%$, Grade 1: fatty infiltration 10\%-50\%, Grade 2: fatty infiltration $>50 \%$
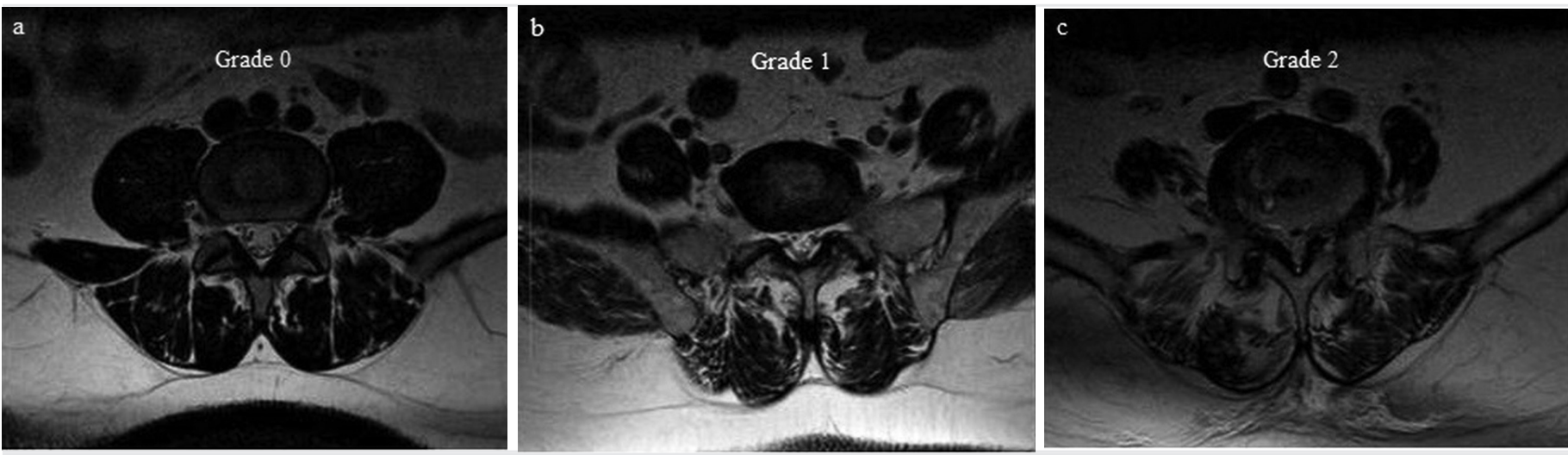

Figure 1. Axial T2-weighted images showing examples of lomber multifidus muscle atrophy. Panel (a) shows grade 0 atrophy: fatty infiltration $<10 \%$; panel (b) shows grade 1 atrophy: fatty infiltration 10\%-50\%; and panel (c) shows grade 2 atrophy: fatty infiltration $>50 \%$
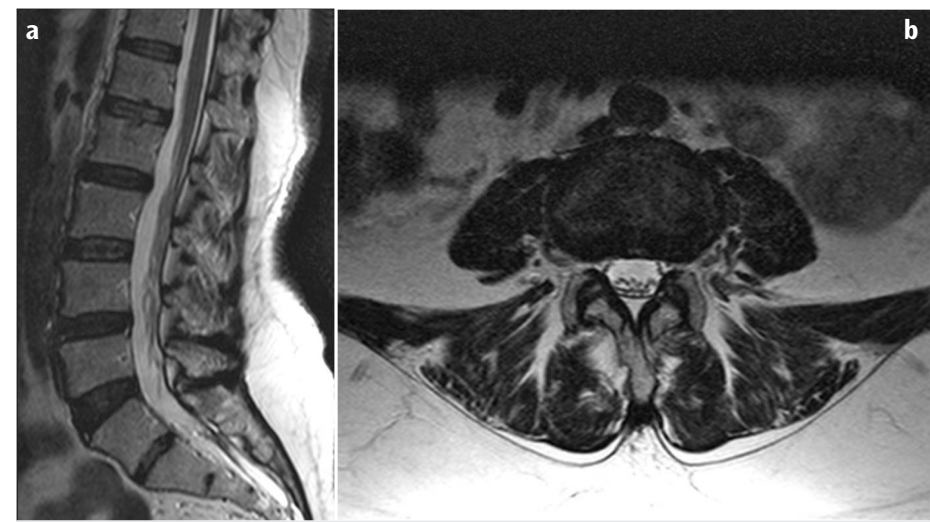

Figure 2. A 53-year-old female patient with grade 1 lomber multifidus (LM) muscle atrophy without disc herniation. Mid-sagittal image (a) showing normal L4-L5 and L5-S1 discs, no significant loss of height or disc herniation. Axial T2WI (b) showing grade 1 LM muscle atrophy at L4-5 level
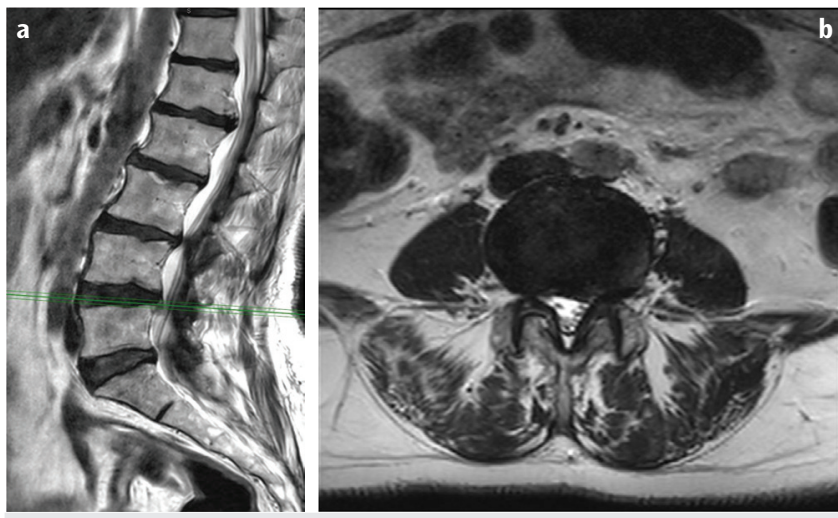

Figure 3. A 63-year-old female patient with intervertebral disc herniation. Mid-sagittal T2-WI (a) showing dehydration and bulging in the discs. Axial T2-WI (b) at L4-L5 level showing left paracentral herniation. Grade 2 atrophy is seen in lomber multifidus muscle 
disorders, inactivity, and chronic diseases can cause muscle atrophy. LM muscle atrophy is more frequent in women. In our study, LM muscle atrophy was also found to be more common in women (73.5\%). There is decline in muscle mass (approximately 8\% for every ten years) after 40 years of age (5). In this study, LM muscle atrophy was found to be more common in females and males older than 40 years $(p<0.001)$.

Morphological changes of the LM muscle can be detected by ultrasonography (US), computed tomography (CT) and MRI (4). US is not preferred for LM muscle assessment due to low tissue contrast and limited field of vision. CT can be used to assess LM muscle changes. However, it requires moderate to high radiation and provides less tissue contrast than MRI. MRI is quite successful in showing changes in LM muscle and additional pathologies in patients with LBP. In addition, MRI provides better soft tissue contrast than CT. MRI does not use ionizing radiation or any other type of radiation (4). LM muscle fatty atrophy is visualized as high intensity areas on T2-weighted sequences. Most of the mobility in the lumbar region emerges from L5-S1 and L4-L5 levels (11). Hence, we evaluated these levels to associate LM muscle with LBP.

Patients with LM muscle atrophy have more lumbar disc herniation than patients without atrophy. In our study, we found grade 1 (53.3\%) LM muscle atrophy in 112 of the 210 patients and grade 2 (18\%) atrophy in 38 patients with lumbar intervertebral disc herniation at any level (Figures 3). We also found that coexistence of disc herniation and LM muscle atrophy at $L 4-5$ levels was associated with age $(p<0.05)$. However, coexistence of disc herniation and LM muscle atrophy at L5-S1 level was not associated with age.

Ekin et al. (5) reported that $13 \%$ of patients with LBP had LM muscle atrophy without disc herniation. In our study, 23 (42.5\%) of 54 patients had grade 1 LM muscle atrophy and 3 patients (5.5\%) had grade 2 atrophy with LBP without lumbar intervertebral disc herniation. In 26 patients (9.8\%) with grade 1 and grade 2 LM muscle atrophy, lumbar MRI was normal. We could not find any explanation of the causes for LBP radiologically, except for LM muscle atrophy. We thought that LM muscle atrophy may be the only finding in patients with LBP.

Woodham et al. (4) reported that spinal manipulative therapy in combination with LM muscle stabilization exercises could reduce LM muscle atrophy. In addition, there is evidence that specific exercise protocols, including multifidus activation, reverse the atrophy of the LM muscle and that these exercises can reduce LBP (13).

MRI is a useful imaging method for the detection of LBP etiology. Malignancy, inflammatory diseases, and infectious processes should be considered in patients with LBP (5). It should be noted that LM muscle atrophy could cause LBP in patients, even those with normal lumbar MRI findings. In our study, $9.8 \%$ of patients with LBP had grade 1 or 2 LM muscle atrophy without lumbar intervertebral disc herniation, spinal stenosis, or nerve root compression.

\section{Conclusion}

The LM muscle is the main stabilizer of the lumbar spine and LM muscle atrophy is closely associated with LBP. In our study, 9.8\% of patients with LBP had grade 1 or 2 LM muscle atrophy without intervertebral disc pathologies or nerve root compression. We believe that LM muscle atrophy can be the only finding in patients with LBP.

Ethics Committee Approval: The University of Health Sciences, Samsun Training and Research Hospital Ethics Committee approval was received for this study (decision no: 2017/24).

Informed Consent: Retrospective study.

Peer-review: Externally and internally peer-reviewed.

Financial Disclosure: The author declared that this study has received no financial support.

\section{References}

1. Altinkaya N, Cekinmez M. Lumbar multifidus muscle changes in unilateral lumbar disc herniation using magnetic resonance imaging. Skeletal Radiol 2016; 45: 73-7.

2. Freeman MD, Woodham MA, Woodham AW. The role of the lumbar multifidus in chronic low back pain: a review. PM R 2010; 2: 142-6; quiz 1 p following 167.

3. Kjaer P, Bendix T, Sorensen JS, Korsholm L, Leboeuf- Yde C. Are MRI-defined fat infiltrations in the multifidus muscles associated with low back pain? BMC Med 2007; 5 : 2 .

4. Woodham M, Woodham A, Skeate JG, Freeman M. Long-term lumbar multifidus muscle atrophy changes documented with magnetic resonance imaging: a case series. J Radiol Case Rep 2014; 8: 27-34.

5. Ekin EE, Kurtul Yıldız H, Mutlu H. Age and sex-based distribution of lumbar multifidus muscle atrophy and coexistence of disc hernia: an MRI study of 2028 patients. Diagn Interv Radiol 2016; 22: 273-6.

6. Hyun JK, Lee JY, Lee SJ, Jeon JY. Asymmetric atrophy of multifidus muscle in patients with unilateral lumbosacral radiculopathy. Spine 2007; 32: 598-602.

7. Kim WH, Lee SH, Lee DY. Changes in the cross-sectional area of multifidus and psoas in unilateral sciatica caused by lumbar disc herniation. J Korean Neurosurg Soc 2011; 50: 201-4.

8. Farshad M, Gerber C, Farshad-Amacker NA, Dietrich TJ, Laufer-Molnar V, Min K. Asymmetry of the multifidus muscle in lumbar radicular nerve compression. Skelet Radiol 2014; 4: 49-53.

9. Battié MC, Niemelainen R, Gibbons LE, Dhillon S. Is level- and side-specific multifidus asymmetry amarker for lumbar disc pathology? Spine J 2012; 12 : 932-9.

10. Parkkola R, Rytokoski U, Kormano M. Magnetic resonance imaging of the discs and trunk muscles in patients with chronic low back pain and healthy control subjects. Spine 1993; 18: 830-6.

11. Kader DF, Wardlaw D, Smith FW. Correlation between the MRI changes in the lumbar multifidus muscles and leg pain. Clin Radiol 2000; 55: 145-9.

12. Wu WW, Hu ZJ, Fan SW, Xu WB, Fang XQ, Zhao FD. Influencing of chronic low back pain on multifidus muscle atrophy. Zhongguo Gu Shang 2014; 27: 207 12.

13. Hides JA, Stanton WR, McMahon S, Sims K, Richardson CA. Effect of stabilization training on multifidus muscle cross-sectional area among young elite cricketers with low back pain. J Orthop Sports Phys Ther 2008; 38: 101-8. 